\title{
The Importance of Food Pulses in Benthic-Pelagic Coupling Processes of Passive Suspension Feeders
}

\author{
Sergio Rossi ${ }^{1,2,3, *(D)}$ and Lucia Rizzo ${ }^{4}$ (D) \\ 1 DiSTeBA, Università del Salento, 73100 Lecce, Italy \\ 2 CONISMA-Consorzio Nazionale Interuniversitario per le Scienze del Mare, 00196 Rome, Italy \\ 3 Labomar, Universidade Federal do Ceará, Fortaleza, CE 60165-081, Brazil \\ 4 Dipartimento di Ecologia Marina Integrata, Stazione Zoologica Anton Dohrn, 80121 Napoli, Italy; \\ lucia.rizzo@szn.it \\ * Correspondence: sergio.rossi@unisalento.it
}

check for updates

Citation: Rossi, S.; Rizzo, L. The Importance of Food Pulses in Benthic-Pelagic Coupling Processes of Passive Suspension Feeders. Water 2021, 13, 997. https://doi.org/ 10.3390/w13070997

Academic Editor: Epaminondas D. Christou

Received: 27 February 2021

Accepted: 31 March 2021

Published: 4 April 2021

Publisher's Note: MDPI stays neutral with regard to jurisdictional claims in published maps and institutional affiliations.

\begin{abstract}
Benthic-pelagic coupling processes and the quantity of carbon transferred from the water column to the benthic suspension feeders need multiple intensive sampling approaches where several environmental variables and benthos performance are quantified. Here, activity, dietary composition, and capture rates of three Mediterranean gorgonians (Paramuricea clavata, Eunicella singularis, and Leptogorgia sarmentosa) were assessed in an intensive cycle considering different variables such as the seston concentration and quality (e.g., carbon, nitrogen, and zooplankton), the colony branch patterns, and the energetic input of the single species (i.e., mixotrophic and heterotrophic). The three species showed clear differences in their impact on the seston concentration. Paramuricea clavata, the most densely distributed, showed a greater impact on the near bottom water column seston. The lowest impact of E. singularis on the seston could be explained by its mixotrophy and colony branching pattern. Leptogorgia sarmentosa had a similar impact as E. singularis, having a much more complex branching pattern and more than an order of magnitude smaller number of colonies per meter square than the other two octocorals. The amount of carbon ingested in the peaks of the capture rates in the three species may cover a non-neglectable proportion of the potential carbon fluxes.
\end{abstract}

Keywords: prey capture rates; octocorals; marine animal forest; optimum forage theory; carbon immobilization; zooplankton; seston

\section{Introduction}

During the last decades, much attention has been paid to the role of megabenthic invertebrate structures composed mainly by invertebrates in benthic-pelagic coupling processes [1]. It is well known that these organisms, mainly active or passive suspension feeders, have a determinant role in biogeochemical cycles and near bottom seston regulation [2]. Biogenic structures produced by sponges, cnidarians, bryozoans, etc., also known as marine animal forests [3,4], may even potentially change, depending on their structure, patch size, and current regime, the seston concentration [5]. The dependence on currents and seston concentration has been claimed as an essential point to understand benthic-pelagic coupling processes [6,7]; nevertheless, there are few studies highlighting the role of short-time cycles as energy providers in marine animal forests.

It is well known that in a brief time (i.e., few hours), the seston concentration in near bottom water layers may suddenly change in concentration and quality [8-11]. Such changes may have an immediate response to the energy fluxes in terms of activity of the benthic community [12-15]. When the benthic activity or the abundance of meiofauna has been analyzed in the deep sea, for example, a fast response to the primary productivity have been found according to different areas of the world, suggesting that the quantity and quality of the organic material transferred from the pelagic to the benthic domain is a 
crucial step to understand the energetic implications of these transfer processes [16-19]. However, nor in shallow or deep waters has a short time approach been adopted in which the seston variables, the activity of the suspension feeders, and the capture rates have been simultaneously quantified to understand the importance of such food pulses in the benthic-pelagic coupling processes.

Several studies indicated that the quality and quantity of the available food would be essential in the understanding of processes determining changes in health status of marine animal forests driven by anthropogenic impacts at local scale in a wider framework of global climate change stressors $[20,21]$. However, to develop reliable models describing changes in energy inputs due to these emerging constrains, it is crucial also to know how short time cycles influence the capture rates in natural conditions, and how fluctuations in seston concentration and food availability may affect the global energy budget of these benthic suspension feeders. Every single community responds differently to the food pulses [20] and knowing the importance of the short-term variability in the prey capture and associated carbon entry may be a key point that has been largely neglected so far [22]. There is a baseline of seston concentration that all the benthic suspension feeders take advantage transversally (i.e., continuously capturing available particles through filtration, depending on the season), but single pulses have been also detected through the year in different marine animal forests [23-25], demonstrating that pulse-like feeding may be essential to understand the overall budget of these invertebrates and its future constraints. In the optimal forage theory [26], all the organisms tend to optimize the available resources for their own benefit with different strategies, including the patch structure and density [27]. In benthic suspension feeders, such optimization depends on the feeding strategy [2,28], being dependent on the seston concentration, quality and the hydrodynamics of the specific area and time of the year. The comprehension of how, in coincidence with the major productivity period of the year, each benthic organism responds in a short time feeding on the available seston will be essential to understand the energetic dynamics of the whole benthic community.

Among the organisms that form the marine animal forests, gorgonians have an important role in benthic-pelagic processes due to their abundance in several habitats of the world [29-33]. In this study, we examined high temporal resolution variability in the polyp expansion and plankton prey captures of three different Mediterranean passive suspension feeders: Eunicella singularis (Esper, 1791), Paramuricea clavata (Risso, 1826), and Leptogorgia sarmentosa (Esper, 1791). Eunicella singularis is a mixotrophic species that feeds on particulate organic carbon [34] but, in shallow areas, relies also in the photosynthetic activity [35]. Its bathymetric distribution range is wide [36], being the morphology and the heterotrophic input different when shallow and deeper populations are compared $[37,38]$. Paramuricea clavata settles preferentially on steep walls [36], it is exclusively heterotrophic, and has a wide diet spectrum, being the zooplankton a significant part of its energy input [30,39]. Leptogorgia sarmentosa prefers detrital-gravel horizontal habitats [36], it is also exclusively heterotrophic, having a diet based in zooplankton, detritus, and picoplankton [40,41].

The goal of the present research is to assess how the food pulses affect the capture rates (in terms of growth and $\mathrm{C}$ uptake and utilization) monitoring the three species in a short-time cycle, having each species a different patch density and colony branching pattern. To do that, we studied the (i) seston quantity and quality in the near bottom water layer, (ii) the polyp activity in the field, and (iii) the prey capture composition and rates of the three different passive suspension feeders at several temporal scales by using an high-frequency temporal sampling. Thus, the present study highlights the role of passive suspension feeders in energy transferring to benthic communities in temperate littoral ecosystems depending on their distribution and also patch density.

\section{Materials and Methods}

The field survey was conducted in the Medes Islands, NW Mediterranean $\left(40^{\circ} 02^{\prime} 55^{\prime \prime} \mathrm{N}\right.$, $3^{\circ} 13^{\prime} 30^{\prime \prime}$ E). Sampling and observations were carried out at 18-20 m depth among a 
coralligenous reef located in a steep wall and boulders. The area was alternately influenced by northerly and southerly currents, which may reach high speeds (from 2 up to $30 \mathrm{~cm} \mathrm{~s}^{-1}$, [10,15]). The underwater topography is markedly asymmetrical, with prominent slopes on the northern side and gentle slopes on the southern side. Strong, dry winds blow from the north-northwest in spring-summer. Water temperature is also highly seasonal, with a strong thermocline between April and October at a depth of 20-30 m (with differences of $7-10^{\circ} \mathrm{C}$ ) [10]. Salinity is usually around $37.5-38 \%$, with maximum values in winter during mixing events produced by heavy storms caused by the north winds [10].

The three species analyzed were octocorals: Paramuricea clavata, Eunicella singularis, and Leptogorgia sarmentosa. Paramuricea clavata has a mean density of 56 colonies $\mathrm{m}^{-2}$, whilst $E$. singularis has a mean density of 41 colonies $\mathrm{m}^{-2}$ in the study area. Leptogorgia sarmentosa has a mean density of 1.5 colonies $\mathrm{m}^{-2}$.

\subsection{Polyp Expansion}

Species polyp expansion was monitored at a high frequency (i.e., two sampling times within the day) during the late spring-early summer. This period was chosen because pelagic primary production and the frequency of seston pulses is high [10]. Expansion is defined as the maximum aperture of polyps [15,42]. Polyp activity was observed in ten groups of five colonies each time by scuba divers in patches distributed along 30-40 meters. On each sampling time, the percentages of expanded semi-expanded or contracted polyps was recorded in colonies of E. singularis, L. sarmentosa, and P. clavata.

\subsection{Environmental and Biological Parameters of the Water Column}

Several environmental and biological variables were concomitantly monitored: (1) seston concentration and quality, the latter determined by assessment of total particulate carbon and nitrogen, chlorophyll a and protein concentrations [10], and (2) zooplankton concentration, determined by analyzing three samples collected by a scuba diver towing a plankton net $(22 \mathrm{~cm}$ in diameter with a mesh size of $100 \mu \mathrm{m})$ for a distance of $40 \mathrm{~m}[30,41]$.

\subsection{Analysis of Gut Contents}

Feeding on plankton in the three species was assessed by means of gut content examinations of apical fragments [41]. The colonies were sampled two times each day during the whole intensive cycle (5 days). Each sample consisted of one apical fragment collected from five randomly selected colonies. The species collected (P. clavata, E. singularis, and $L$. sarmentosa) are not protected species; we have a specific permit to operate and sample in the area from the local authorities, the Parc Natural de les Illes Medes.

The fragments were immediately placed in $10 \%$ formaldehyde solution in seawater to prevent further digestion. The contents of 50 polyps selected randomly from each sample (ten from each apical fragment of five colonies in each sampling time per each species) were isolated by dissection under a binocular microscope, identified to the higher taxon level and counted. The length of all prey was measured under the microscope with a micrometer ruler.

\subsection{Benthic-Pelagic Coupling Calculations \\ 2.4.1. Prey Capture Rate}

The zooplankton capture rate, expressed as the number of prey items captured per polyp and hour, was calculated using the following equation [30]:

$$
\mathrm{C}=\mathrm{N}\left[\sum_{\mathrm{t}=0}^{\mathrm{D}} 1-\left(\frac{\mathrm{t}}{\mathrm{D}}\right)\right]^{-1}
$$

where $C$ is the number of preys captured per polyp per hour, $\mathrm{N}$ is the number of prey items per polyp, $\mathrm{t}$ is time (in hours), and $\mathrm{D}$ is digestion time (in hours). Digestion time applied for the three species considered the temperature recorded $\left(19.5^{\circ} \mathrm{C}\right.$, [10]) in the study area 
in this time of the year. The applied digestion time is based on the available literature of $E$. singularis and L. sarmentosa $[34,41]$; no data on $P$. clavata digestion time at this temperature range has been calculated in previous studies; thus, the previous two species digestion was also used to make the P. clavata calculations on prey capture rates.

\subsubsection{Prey Biomass}

Prey biomass was estimated from biovolumes [43], using conversion factors for wet weight (1.025; [44]), dry weight (13\% of wet weight, [45]), and carbon content (45\% of dry weight, [46]), as per Rossi et al. [41].

\subsubsection{Potential Impact on Seston}

To understand how much seston is needed to satisfy the needs of a single polyp during the day, a combined approach was applied.

First, the total seston concentration, minimum and maximum total carbon values across the sampling times were estimated. The obtained values were multiplied by the coefficient 0.66 , as it has been shown that in this area, the inorganic carbon represents approximately $33 \%$ of the seston [47]. Those quantities represent the organic carbon (i.e., 105.5 and $267.9 \mu \mathrm{g} \mathrm{C} \mathrm{L}{ }^{-1}$, respectively). Then, the obtained values were divided by the maximum ingesta of a single polyp throughout the entire cycle (values found in the present study, see below). This number will represent the potential quantity of polyps of each species that may feed with one litre of near bottom seawater in minimum and maximum seston concentration across the sampling times.

Second, the minimum and maximum zooplankton concentration values throughout the sampling times (i.e., 533 and 8437 zooplankters $\mathrm{m}^{-3}$, respectively; values found in the present study, see below) were estimated. Then, the obtained values were divided by the maximum ingesta of a single polyp throughout the entire cycle. This number will be the potential number of polyps of each species that may withstand with one cubic meter of near bottom water in minimum and maximum zooplankton concentration across sampling times.

\subsection{Statistical Analysis}

The variability in seston composition (total particulate carbon and nitrogen, chlorophyll a, and protein concentrations) and zooplankton density was assessed at several temporal scales by multivariate analyses. The design consisted of two factors: Day (D, as a random factor with 5 levels, each $24 \mathrm{~h}$ ) and Time ( $\mathrm{T}$, as a random factor with 2 levels, nested in $\mathrm{D}$, twice per day), with $\mathrm{n}=3$. Multivariate analyses of variance (PERMANOVA, [47]) was performed based on Euclidean distances of previously normalized data, using 9999 random permutations of the appropriate units [48].

To assess differences in polyp expansion, fed polyp percentages and prey biomass of fed polyps belonging to the three investigated species, univariate permutational analyses of variance (PERMANOVA, [47]) were performed, based on Euclidean distances of untransformed data, using 9999 random permutations of the appropriate units [48]. Differences in prey composition were assessed performing permutational analyses of variance (PERMANOVA, [47]) based on Bray Curtis dissimilarities. The design adopted consisted of three factors: Day (D, as a random factor with 5 levels, each $24 \mathrm{~h}$ ) Time (T, as a random factor with 2 levels, nested in D, twice per day), and Species (S, as fixed factor with 3 levels) with $\mathrm{n}=5$.

Finally, in order to assess differences in gut contents of colonies belonging to the three gorgonian species, multivariate permutational analyses of variance (PERMANOVA, [47]) were performed based on Bray Curtis similarities of untransformed data adding a dummy variable, using 9999 random permutations of the appropriate units [48]. The experimental design consists of four factors: Day (D, as a random factor with 5 levels, each $24 \mathrm{~h}$ ) Time ( $\mathrm{T}$, as a random factor with 2 levels, nested in $\mathrm{D}$, twice per day), Species ( $\mathrm{S}$, as fixed factor with 3 levels), and Colony (C, as random factor nested in $S$, with 5 levels), with $n=10$. 
When significant differences were encountered $(p<0.05)$, post-hoc pairwise tests were carried out in order to ascertain the consistency of the differences across the different conditions tested. Because of the restricted number of unique permutations in the pairwise tests, $p$-values were obtained from Monte Carlo tests. To examine the generality of patterns in seston and zooplankton densities, and prey composition of fed polyps, Multidimensional Scaling (MDS) plots were generated. The analyses were performed using PRIMER v. 6 software [49] including the PERMANOVA + add-on package [49,50].

\section{Results}

\subsection{Seston and Zooplankton Density}

Zooplankton concentration varied between 533 individuals $\mathrm{m}^{-3}$ and 8437 individuals $\mathrm{m}^{-3}$ (Table S1). Zooplankton had higher concentrations toward the latter days (Figure 1). Contrariwise, chlorophyll a had its higher concentration values at the beginning of experiment. Chlorophyll a concentration varied between 0.29 and $0.57 \mu \mathrm{g} \mathrm{L}^{-1}$, with a mean of $0.40 \pm 0.01 \mathrm{SE} \mu \mathrm{g} \mathrm{L}^{-1}$. Protein and total carbon contents exhibited a similar trend. Protein concentration minimum value was $127 \mu \mathrm{g} \mathrm{L}^{-1}$, maximum value was $244 \mu \mathrm{g} \mathrm{L}^{-1}$. The mean concentration was $182 \pm 5 \mathrm{SE} \mu \mathrm{g} \mathrm{L}^{-1}$. The mean concentration of total carbon contents was $247 \pm 13 \mathrm{SE} \mu \mathrm{g} \mathrm{L}^{-1}$, with the maximum value of $406 \mu \mathrm{g} \mathrm{L}^{-1}$ and the minimum value of $160 \mu \mathrm{g} \mathrm{L}{ }^{-1}$. The mean concentration of total nitrogen was $22 \pm 1 \mathrm{SE} \mu \mathrm{g} \mathrm{L}^{-1}$, with the maximum value of $34 \mu \mathrm{g} \mathrm{L}^{-1}$ and a minimum of $13 \mu \mathrm{g} \mathrm{L}^{-1}$. The total seston concentration ranged from 159.9 to $405.9 \mu \mathrm{g} \mathrm{C} \mathrm{L} \mathrm{L}^{-1}$.

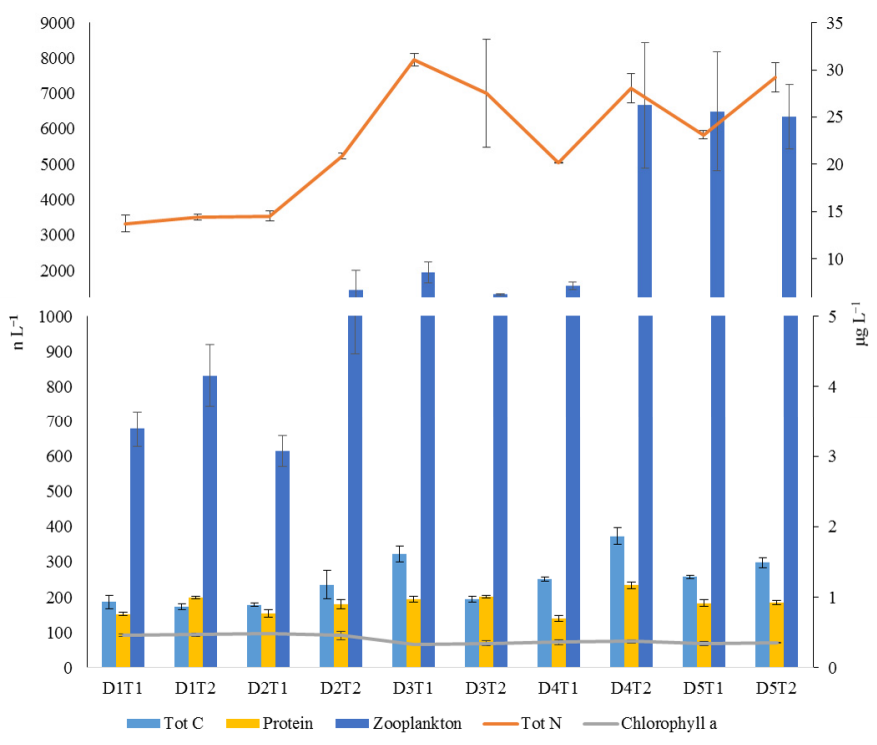

Figure 1. The seston (total carbon, protein, total nitrogen, and clorophyll a; right axis) and zooplankton variables (left axis) characterizing the several sampling times within the sampling days.

The results of the multivariate PERMANOVA revealed that the seston and zooplankton composition varied significantly among sampling times of days (Table 1).

MSD plot showed a segregation among several sampling times of the first and last days, which is mostly correlated by the increased contents of protein, zooplankton, total carbon, and nitrogen contents in the sampling times of latter days. Instead, the sampling times related to the two first days were correlated to a slight increment of chlorophyll a (Figures 1 and 2). 
Table 1. Results of multivariate permutational analyses (PERMANOVA) on seston and zooplankton composition across several temporal scales (Day, Time).

\begin{tabular}{|c|c|c|c|c|}
\hline Source & Df & MS & Pseudo-F & P (Perm) \\
\hline $\mathrm{D}$ & 4 & 18.68 & 2.24 & \\
\hline $\mathrm{T}(\mathrm{D})$ & 5 & 8.36 & 5.87 & $* * *$ \\
\hline Res & 20 & 1.42 & & \\
\hline Total & 29 & & & \\
\hline
\end{tabular}

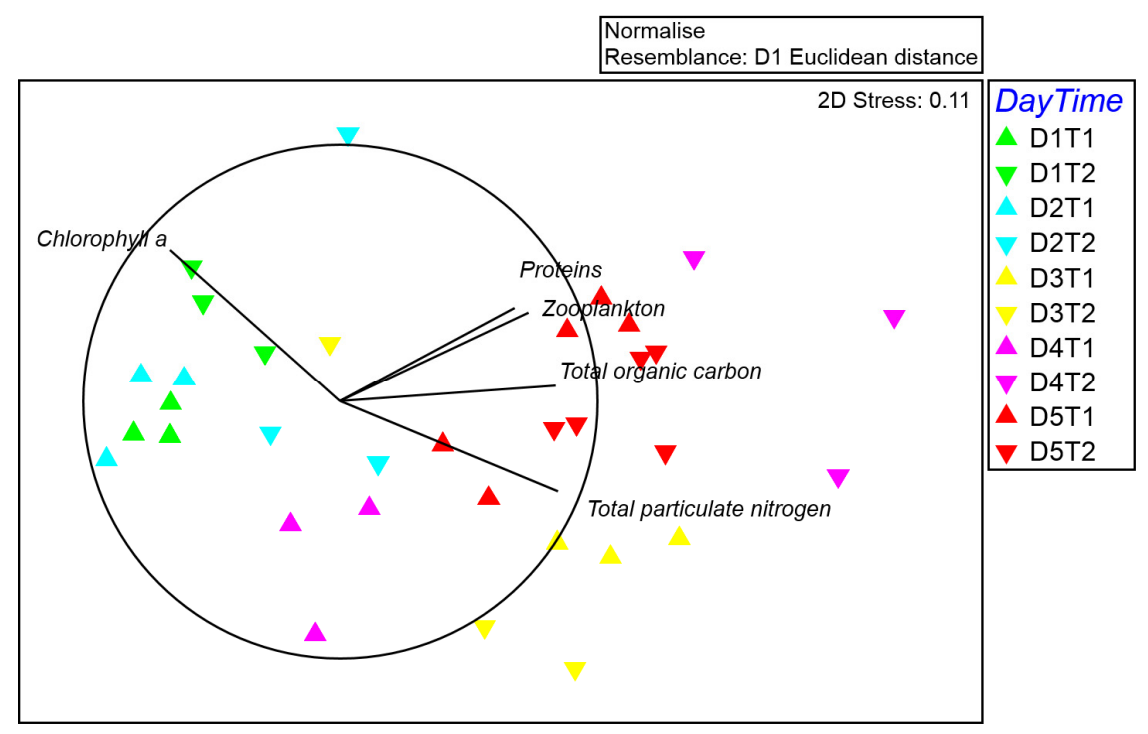

Figure 2. Multidimensional scaling (MDS) plot for seston composition with Euclidean distances based on normalized data; vectors with Pearson's correlation coefficients display environmental variables.

\subsection{Polyp Expansion and Fed Polyp Observation of the Three Gorgonians}

Overall, 1500 polyps (500 for each species) were analyzed finding 49 fed polyp for Eunicella, 95 for Leptogorgia, and 157 for Paramuricea). The results of the PERMANOVA revealed significant differences in the percentage of fed polyps among species and sampling times (Table 2).

Table 2. Results of permutational analyses (PERMANOVA) on the percentages of fed, open, semi-open, closed polyps in the species investigated across several temporal scales (Day, Time).

\begin{tabular}{|c|c|c|c|c|c|c|c|c|c|c|c|c|c|}
\hline \multirow[b]{2}{*}{ Source } & \multirow[b]{2}{*}{ Df } & \multicolumn{3}{|c|}{ Fed Polyps \% } & \multicolumn{3}{|c|}{ Open Polyps \% } & \multicolumn{3}{|c|}{ Semi-Open Polyps \% } & \multicolumn{3}{|c|}{ Closed Polyps \% } \\
\hline & & MS & $\begin{array}{l}\text { Pseudo- } \\
\text { F }\end{array}$ & P (Perm) & MS & $\begin{array}{l}\text { Pseudo- } \\
\text { F }\end{array}$ & P (Perm) & MS & $\begin{array}{l}\text { Pseudo- } \\
\text { F }\end{array}$ & $\begin{array}{c}P \\
\text { (Perm) }\end{array}$ & MS & $\begin{array}{l}\text { Pseudo- } \\
\text { F }\end{array}$ & $\begin{array}{c}P \\
\text { (Perm) }\end{array}$ \\
\hline $\mathrm{D}$ & 4 & 45.51 & 2.59 & $\mathrm{~ns}$ & 137.8 & 1.22 & & 8.72 & 0.69 & & 105.78 & 1.21 & \\
\hline$S$ & 2 & 58.75 & 9.37 & $* * *$ & 76.51 & 6.01 & & 26.93 & 1.74 & & 47.33 & 1.66 & \\
\hline $\mathrm{T}(\mathrm{D})$ & 5 & 17.58 & 10.16 & $* * *$ & 112.86 & 39.88 & & 12.66 & 7.42 & & 87.69 & 25.89 & \\
\hline $\mathrm{D} \times \mathrm{S}$ & 8 & 6.27 & 2.10 & ns & 12.74 & 0.41 & & 15.5 & 1.44 & & 28.59 & 1.04 & \\
\hline $\begin{array}{l}\mathrm{T}(\mathrm{D}) \times \\
\mathrm{S}\end{array}$ & 10 & 2.98 & 1.72 & ns & 31.28 & 11.05 & $* * *$ & 10.8 & 6.33 & $* * *$ & 27.39 & 8.09 & $* * *$ \\
\hline Res & 120 & 1.73 & & & 2.83 & & & 1.71 & & & 3.39 & & \\
\hline Total & 149 & & & & & & & & & & & & \\
\hline
\end{tabular}

*** $p<0.001 ;$ ns- not significant.

In particular, pairwise analyses showed significant differences between E. singularis and $P$. clavata (Table 3), while did not underline differences between E. singularis and $L$. sarmentosa and between L. sarmentosa and P. clavata. 
Table 3. Results of the pairwise tests contrasting the percentages of fed polyps of the three species across several temporal scales.

\begin{tabular}{ccc}
\hline Pairwise Tests & T & P (Perm) \\
\hline E. singularis vs. L. sarmentosa & 2.00 & $\mathrm{~ns}$ \\
E. singularis vs. P. clavata & 5.49 & $* *$ \\
L. sarmentosa vs. P. clavata & 2.00 & $\mathrm{~ns}$ \\
\hline$* * 001 \cdot$ ns- not significant & &
\end{tabular}

** $p<0.01 ;$ ns- not significant.

Moreover, the percentages of open, semi-open, closed polyps were assessed in the species investigated. The analyses on polyp expansion (open, semi-open, and closed status) of the three species investigated showed the significant $T(D) \times S$ term indicating that the polyp status of the species varied significantly at varying of sampling times of cycles (Table 2). In particular, pairwise analyses showed significant differences among species in some sampling times of the days (Table S2, Figure 3), except for D2T2 D3T1 D4T2 and D5T2 when there were no differences in closed polyp percentage, and D5T2 in semi-open polyp percentage among all species investigated.

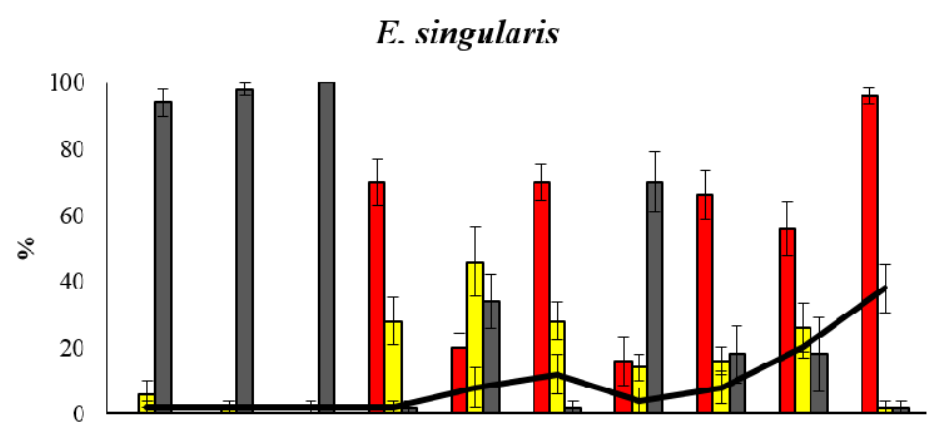

L. sarmentosa

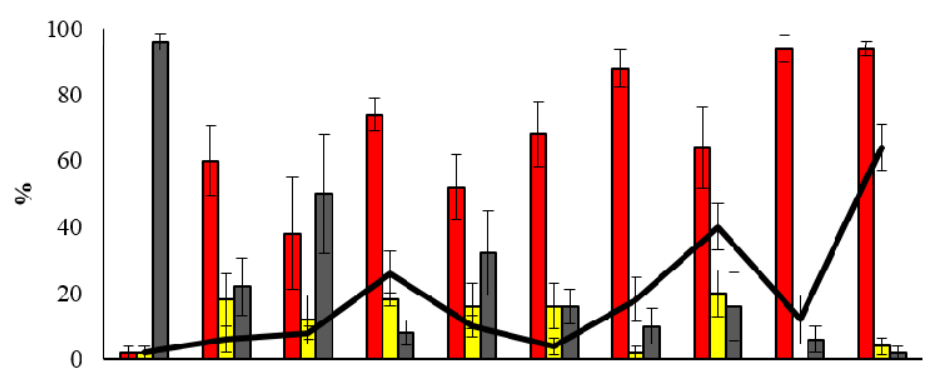

P. clavata

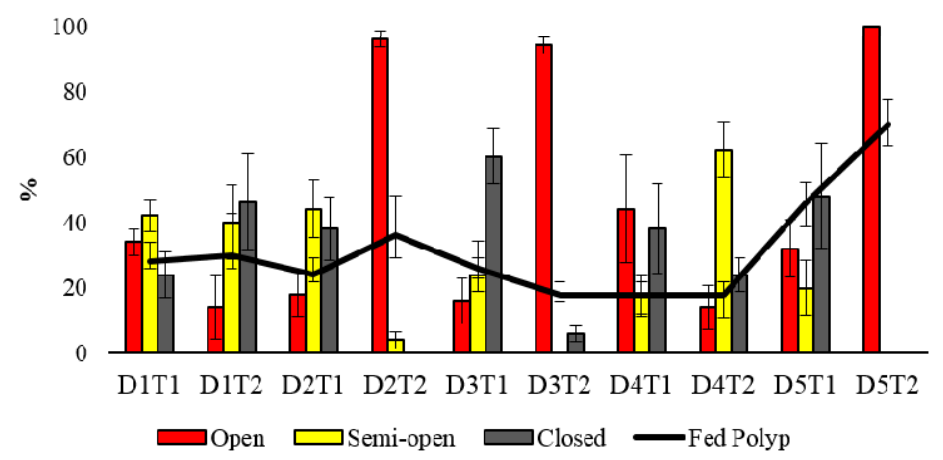

Figure 3. The polyp expansion and nutritional status of the three species. 


\subsection{Gut Contents of Gorgonian Polyps}

Regarding the prey captures, from the analyses of 1500 polyps (500 for each species collected in all sampling times), 1199 empty polyps and 891 preys were found reaching 301 fed polyps taking together all the investigated species.

The result of the multivariate PERMANOVA on gut composition revealed a significant $\mathrm{T}(\mathrm{D}) \times \mathrm{C}(\mathrm{S})$ term, underlining a great variability among colonies of the three different species across sampling times (Table 4, Table S3).

Table 4. Results of multivariate permutational analyses (PERMANOVA) on gut contents of polyps of different colonies of three species investigated across several temporal scales (Day, Time).

\begin{tabular}{ccccc}
\hline Source & Df & MS & Pseudo-F & P (Perm) \\
\hline $\mathrm{D}$ & 4 & 3892.50 & 1.98 & \\
$\mathrm{~S}$ & 2 & 6464.70 & 3.70 & \\
$\mathrm{~T}(\mathrm{D})$ & 5 & 1728.30 & 4.15 & \\
$\mathrm{C}(\mathrm{S})$ & 12 & 564.36 & 1.25 & \\
$\mathrm{D} \times \mathrm{S}$ & 8 & 1307.50 & 1.55 & ns \\
$\mathrm{D} \times \mathrm{C}(\mathrm{S})$ & 48 & 452.62 & 1.09 & $* *$ \\
$\mathrm{~T}(\mathrm{D}) \times \mathrm{S}$ & 10 & 660.15 & 1.59 & \\
$\mathrm{~T}(\mathrm{D}) \times \mathrm{C}(\mathrm{S})$ & 60 & 416.48 & 1.30 & \\
Res & 1350 & 321.28 & & \\
Total & 1499 & & &
\end{tabular}

\subsection{Prey Composition and Biomass}

Regardless of the sampling times, the species with the highest prey capture rate is $P$. clavata, followed by $L$. sarmentosa and E. singularis. Total prey captures are 891 preys for $P$. clavata (5.68 $\pm 2.16 \mathrm{SE}$ prey/fed polyp), 130 preys for L. sarmentosa (1.37 $\pm 0.08 \mathrm{SE}$ prey/fed polyp), and 57 for E. singularis (1.16 $\pm 0.07 \mathrm{SE}$ prey/fed polyp) (Figure 4).

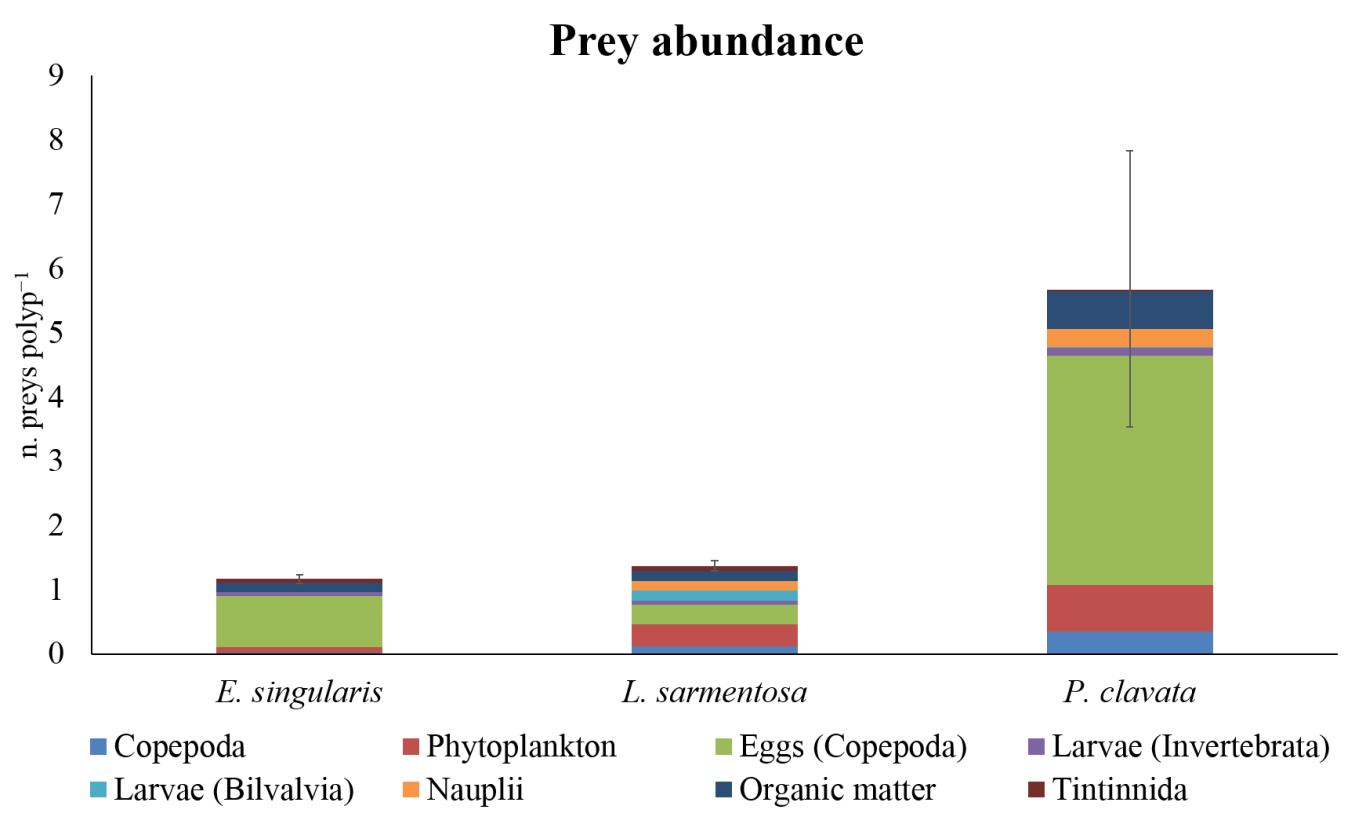

Figure 4. Prey abundances in the fed polyps of the three investigated species.

The results of the PERMANOVA revealed a significant $\mathrm{D} \times \mathrm{S}$ term, indicating differences among the three species at varying of the sampling days (Table 5), as showed in detail by pairwise analyses (Table 6 ). 
Table 5. Results of permutational analyses (PERMANOVA) on prey composition, and prey biomass of polyps of the three species investigated across several temporal scales (Day, Time).

\begin{tabular}{cccccccc}
\hline & \multicolumn{3}{c}{ Prey Composition } & \multicolumn{3}{c}{ Total Prey Biomass } \\
\hline Source & Df & MS & Pseudo-F & P (Perm) & MS & Pseudo-F & P (Perm) \\
\hline D & 4 & 3447.20 & 0.81 & & 0.26 & 0.51 & $\mathrm{~ns}$ \\
S & 2 & $22,981.00$ & 4.09 & & 4.86 & 3.97 & $\mathrm{~ns}$ \\
$\mathrm{~T}(\mathrm{D})$ & 5 & 4394.50 & 1.23 & & 0.25 & 0.13 & $\mathrm{~ns}$ \\
$\mathrm{D} \times \mathrm{S}$ & 8 & 6458.60 & 1.69 & $*$ & 0.95 & 1.11 & $\mathrm{~ns}$ \\
$\mathrm{~T}(\mathrm{D}) \times \mathrm{S}$ & 10 & 3860.60 & 1.08 & $\mathrm{~ns}$ & 0.71 & 0.37 & $\mathrm{~ns}$ \\
Res & 271 & 3583.10 & & & 1.89 & & \\
Total & 300 & & & & & &
\end{tabular}

Table 6. Results of the pairwise tests contrasting the prey compositions of polyps of the three species across sampling days. S1: Eunicella singularis, S2: Leptogorgia sarmentosa, S3: Paramuricea clavata.

\begin{tabular}{|c|c|c|c|c|c|c|c|c|c|c|}
\hline Groups & $\mathrm{T}$ & $\mathbf{P}(\mathrm{MC})$ & $\mathrm{T}$ & $\mathrm{P}(\mathrm{MC})$ & $\mathrm{T}$ & $\mathrm{P}(\mathrm{MC})$ & $\mathrm{T}$ & $\mathbf{P}(\mathrm{MC})$ & $\mathrm{T}$ & $\mathrm{P}(\mathrm{MC})$ \\
\hline & D1 & & D2 & & D3 & & D4 & & D5 & \\
\hline $\begin{array}{l}\text { S1 vs. } \\
\text { S2 }\end{array}$ & 1.29 & ns & 0.77 & ns & 2.79 & ns & 4.10 & $* *$ & 2.43 & $*$ \\
\hline $\begin{array}{c}\text { S1 vs. } \\
\text { S3 }\end{array}$ & 1.05 & ns & 0.91 & ns & 4.78 & $* *$ & 2.20 & ns & 3.14 & * \\
\hline $\begin{array}{c}\text { S2 vs. } \\
\text { S3 }\end{array}$ & 1.73 & ns & 1.15 & ns & 1.35 & ns & 2.00 & ns & 1.43 & ns \\
\hline
\end{tabular}

Differences among species were represented by multidimensional scaling ordinations (MDS) (Figure 5), considering sampling time centroids (the mean cover values of each species in each sampling time of the day).

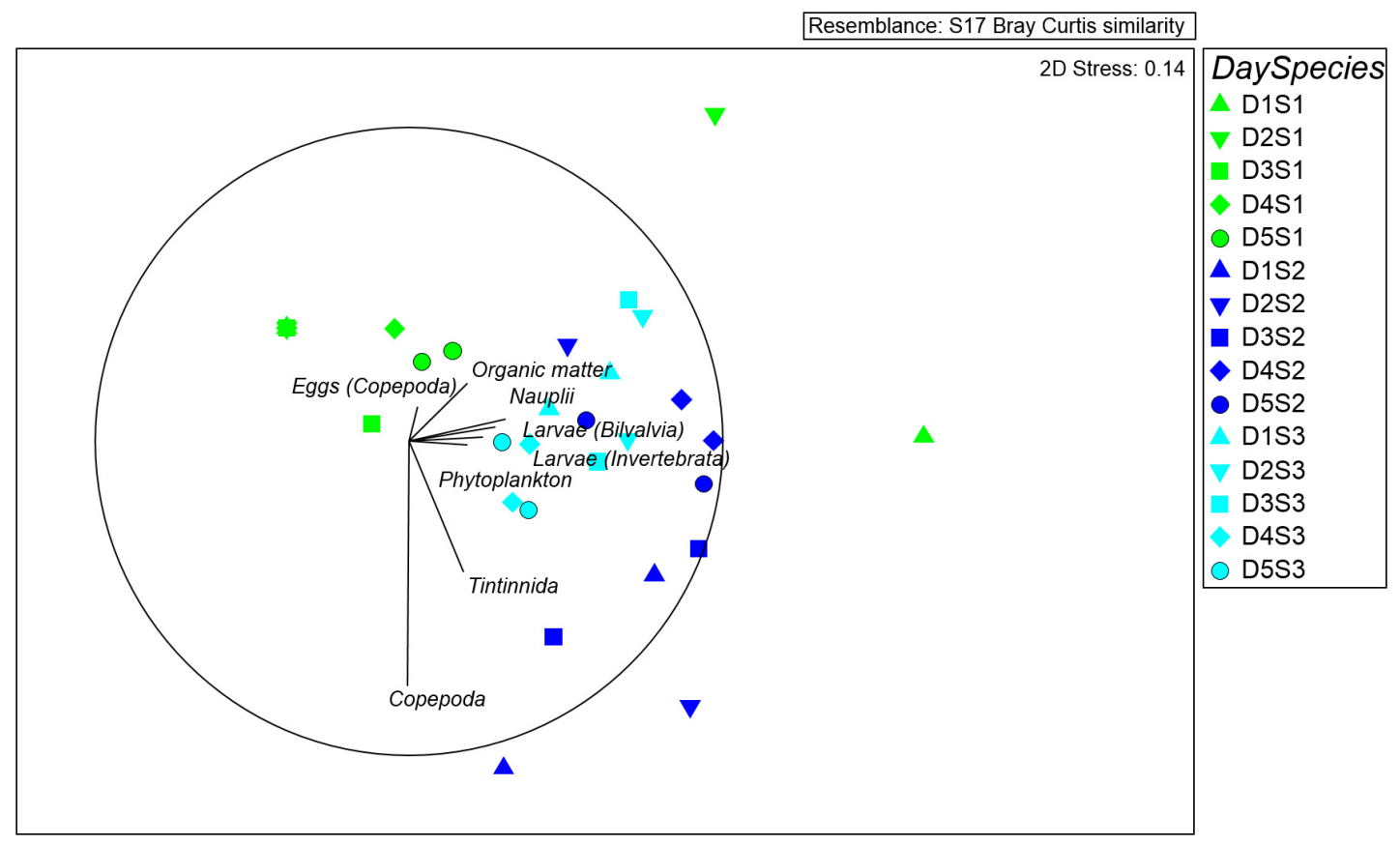

Figure 5. Multidimensional scaling (MDS) plot of the three investigated species based on sampling time centroids; vectors with Pearson's correlation coefficients display prey abundance variables. 
Total prey biomass accounted for a total of $136.43 \mu \mathrm{g} \mathrm{C}$. The main species able to store carbon is P. clavata (tot $105.01 \mu \mathrm{g} \mathrm{C} ; 0.67 \pm 0.15 \mathrm{SE} \mu \mathrm{g} \mathrm{C}$ / fed polyp), followed by $E$. singularis (tot $13.00 \mu \mathrm{g} \mathrm{C} ; 0.27 \pm 0.05 \mathrm{SE} \mu \mathrm{g} C$ / fed polyp), and L. sarmentosa (tot, $18.42 \mu \mathrm{g}$ C; $0.19 \pm 0.02 \mathrm{SE} \mathrm{\mu g} \mathrm{C} \mathrm{/fed} \mathrm{polyp)} \mathrm{(Figure} \mathrm{6).} \mathrm{Nevertheless,} \mathrm{because} \mathrm{of} \mathrm{the} \mathrm{large} \mathrm{variability,}$ the results of the PERMANOVA on prey biomass revealed no significant differences across investigated factors (Table 6, Figure 6).

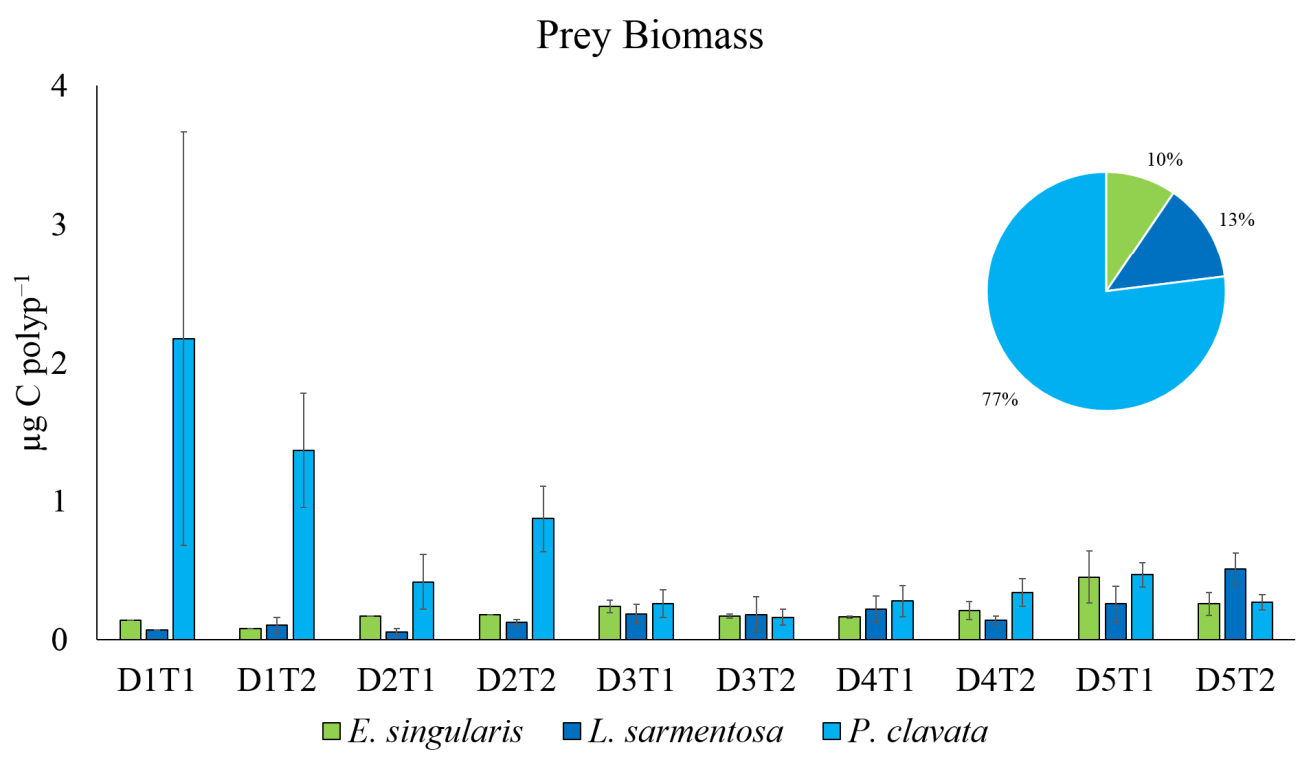

Figure 6. Prey biomass in fed polyps of the three investigated species.

\subsection{Benthic-Pelagic Coupling Calculations: Potential Impact on Seston}

Tables 7 and 8 summarize the potential number of polyps of the three studied species feeding on the seston and zooplankton, respectively, contained in a specific volume measure (i.e., one liter or one cubic meter of seawater).

Table 7. Impact on the organic carbon (water near bottom seston) of the three studied species. The number of polyps feeding on seston is the ratio between the organic $C$ (minimum and maximum) found in one liter $\left(\mathrm{L}^{-1}\right)$ of sea water and the maximum organic matter found in the polyps of each species (calculations made per day).

\begin{tabular}{|c|c|c|c|c|}
\hline Species & $\begin{array}{l}\text { Max Food Pulse } \\
(\mu g \text { C polyp }\end{array}$ & $\begin{array}{l}\text { Min Organic C } \\
\left(\mu g \mathrm{C} \mathrm{L}^{-1}\right)\end{array}$ & $\begin{array}{c}\text { Max Organic C } \\
\left(\mu g \mathrm{CL}^{-1}\right)\end{array}$ & $\begin{array}{l}\text { Max Number of Polyps } \\
\text { Feeding on the Seston }\end{array}$ \\
\hline Paramuricea clavata & 10.42 & 105.5 & 267.9 & $10 / 25$ \\
\hline Leptogorgia sarmentosa & 2.27 & 105.5 & 267.9 & $46 / 118$ \\
\hline Eunicella singularis & 2.15 & 105.5 & 269.9 & $49 / 124$ \\
\hline
\end{tabular}

Table 8. Impact on the zooplankton (water near bottom seston) of the three studied species. The number of polyps feeding on zooplankton is the ratio between the zooplankters in the short time cycle (minimum and maximum) found in one cubic meter $\left(\mathrm{m}^{3}\right)$ of sea water and the maximum prey found in the polyps of each species (calculations made per day).

\begin{tabular}{ccccc}
\hline Species & $\begin{array}{c}\text { Max Food Pulse } \\
\text { (Prey Polyp }\end{array}$ & $\begin{array}{c}\text { Min Zooplankton } \\
\text { (Ind m }^{-3} \text { ) }\end{array}$ & $\begin{array}{c}\text { Max Zooplankton } \\
\text { (Ind m }^{-3} \text { ) }\end{array}$ & $\begin{array}{c}\text { Max Number of Polyps Feeding } \\
\text { on the Zooplankton }\end{array}$ \\
\hline Paramuricea clavata & 139.2 & 533 & 8437 & $4 / 60$ \\
Leptogorgia sarmentosa & 8.40 & 533 & 8437 & $63 / 1004$ \\
Eunicella singularis & 6.57 & 533 & 8437 & $81 / 1284$ \\
\hline
\end{tabular}


The calculation took into account changes in the sampling times, in term of minimum and maximum values recorded during the present intensive cycle. As reported in table, the minimum seston organic carbon content can satisfy 10 P. clavata polyps when they are in their maximum feeding $\left(10.42 \mu \mathrm{g} \mathrm{C}\right.$ polyp $\left.^{-1}\right)$, whilst the maximum seston organic carbon content will satisfy 25 polyps having the same capture rates $\left(10.42 \mu \mathrm{g} \mathrm{C}_{\text {polyp }}{ }^{-1}\right.$ ) (Table 8$)$. A similar procedure is applied for the zooplankton, considering the individuals in one cubic meter. The estimations of other two investigated species are reported in Table 8 as well.

\section{Discussion}

In the present paper, for the first time, seston variables and prey capture rates are contrasted in different species of passive suspension feeders with different colony densities, analyzing the potential relations throughout a short time cycle. It has been reported that, to make energetic balances, short time cycles may be essential although neglected [51].

Seston variables found in the present study (including zooplankton) are in line with the variability found in previous Mediterranean studies in which coastal or near bottom water column parameters were analyzed [30,41,52-54]. Wide variations in a short time, especially in zooplankton, have been however seldom analyzed in near bottom seston in warm temperate seas and have been considered as an obstacle to understand the potential mechanisms in benthic-pelagic coupling processes [10,55].

The present work is also in line with previous findings on the diet and capture rates (maximum and minimum) observed in annual cycles in the three studied species [30,34,41], however several peaks of ingesta have been recorded that in seasonal sampling are difficult to detect. These peaks demonstrate that, in only few hours, the energy input may be even more than an order of magnitude higher in species like P. clavata, but also noteworthy in $E$. singularis and L. sarmentosa.

The present high-frequency monitoring does not show a clear coupling between the activity and the seston concentration. It represents, however, a first insight into the complex mechanisms among the seston variables (concentration), the polyp activity and the species diet. The seston concentration (or quality, see the protein concentration) was not clearly related to the gut contents even taking both variables contextually (seston and polyps) through a high-frequency sampling. Rossi et al. [15] showed that the polyp opening in another octocoral, Corallium rubrum, due to the presence of a nutritional stimulus (chemical signals or zooplankton) in controlled experiments, may be 1-3 minutes. The activity (opening polyps) of the three gorgonians studied though a field experiment seems not to be affected to the seston concentration or quality since the elapsed time between the high signals (i.e., high zooplankter concentration for example) and the polyp opening may happen quickly and non-detectable even with such an intensive cycle. At this temperature $\left(19.5^{\circ} \mathrm{C}\right)$, the three species seem to follow similar patterns to those found in previous studies of these or other octocorals $[15,56]$. However, the present observations highlight that the fed polyps are often in coincidence with high concentration of seston and zooplankton density. Benthic macrofaunal response to pelagic production can cover different time ranges according to physiology and ecology of the considered species, as also underlined by observations and model simulation [57].

Digestion time, being relatively slow at $19.5^{\circ} \mathrm{C}$ (the temperature found in the water column in the area during the sampling [10]), may be essential to understand the underlining trophic dynamics. The prey abundance in gut contents could reflect the preys caught nine hours before. In fact, sudden changes of the seston concentration in only few hours are well-known $[10,11]$, representing the opportunity to retain the particles limited in time for benthic suspension feeders [51].

Our findings report a clear difference among the investigated species in the food pulse behavior in term of capture rates (and in different times of the cycle). Paramuricea clavata has the highest prey abundance in gut contents that, transformed in captured organic carbon, indicates the highest energy input among the three species. In the study area, $P$. 
clavata lives on vertical rocky walls, as reported in other studies [36], on a large boulder [58], forming crowded patches (around 56 colonies $\mathrm{m}^{-2}$, [30]). The density of colony patches of E. singularis was lower than P. clavata in the study area $\left(41\right.$ colonies $\left.\mathrm{m}^{-2},[59]\right)$, and sparse colonies were found in the case of L. sarmantosa $\left(1.5\right.$ colonies $\mathrm{m}^{-2}$, [41]). Nelson and Bramanti [27] suggested that the density and population structure/ramification of the gorgonian forests can be crucial to understand the efficient capture rates, since the high-density patches are able to retain the particles for longer times potentially [5]. Coma et al [60] found that, in the rocky coasts of Menorca, after a mass mortality event, highdensity patches of E. singularis were affected by lower mortality rates when compared with patches hosting low-density colonies. This species relies on the autotrophic input to be successful in shallow waters [35,38]), with low number of longer primary branches in the colonies respect those found in deeper waters [38].

The capture rates of E. singularis are comparable with those of L. sarmentosa: a poor branching pattern possibly structured for light harvesting [61] and a non-effective cnidocilia density in the polyps [34] may be essential to understand why the numbers of incoming carbon by heterotrophy are not similar to those of $P$. clavata. Rossi et al. [25] also suggested that the patch density in mixotrophic species may be one of the keys to understanding colony efficiency in the energy inputs. The species studied (Pterogorgia anceps, Caribbean Sea) had similar capture rates to E. singularis. Leptogorgia sarmentosa, being in the study area the least dense among the three species investigated ( 1.5 colonies $\mathrm{m}^{-2}$ [41]) is highly branched [62]. Thus, its capture rates are quite high if we compare with the crowded colonies of $P$. clavata. It suggests that indeed the colony density can be essential to be largely efficient capturing particles in gorgonians, together with the exposition of the colonies [58]. Further investigations applying high-frequency temporal approaches at large spatial scales will compare different ranges of the density of $L$. sarmentosa to assess the capture efficiency of this sand-gravel suspension feeder. The observations on P. clavata were made in a vertical wall exposed to the currents, a preferential settlement of the species [36]. This position can enhance the prey capture rates, making this species particularly efficient in seston retention. We suggest that, beyond the exposition of the patch (vertical instead of horizontal [58]), and polyp size and morphology [63], the density of the colonies [27] represent key factors to understand the optimization of the prey capture rates. Even if the final target of the present experimental design was not to demonstrate the effect of the patch density in the beginning, our results shed a first light on the relationship between the colony density and branching pattern and the capture rates in the intensive cycle. Campanyà-Llovet et al. [20] stressed that food quantity and quality will be essential to understand the future of megabenthic communities in different areas of the world. Indeed, the synergy of currents and seston concentration may be the key to understanding prey capture rates in passive suspension feeders [15]. However, as also suggested by Nelson and Bramanti [27], other relevant factors as patch density, position, colony branching pattern, and the mixotrophic or heterotrophic nature of the gorgonians can affect the efficiency in these capture rates with associated consequences on carbon cycling and immobilization [64,65]. Rossi et al. [21] also highlighted this issue, stressing the importance of studies on the effects of primary and secondary productivity changes driven by climate change, which will shape the future seascape.

\section{Conclusions}

The availability of food quantity and quality and environmental conditions pose important constrains to mega-benthic communities in different areas of the world. Our results point out the coexistence of potential factors such as patch density, position, colony branching pattern, and the mixotrophic or heterotrophic nature, playing a key role in efficiency optimization of capture rates. Here, we discussed the potential role of mature and dense gorgonian populations as the key to understanding high impacts on seston. Food pulses (a significant change in seston availability in a short time) could be essential to understand carbon cycling and immobilization. To understand the role of marine animal 
forests as carbon immobilizers, future efforts should be focused on the real energy inputs, stimulating research studies addressed to detect the real benthic-pelagic coupling processes through intensive cycles. Future research should be addressed on the effects of primary and secondary productivity changes driven by climate change, which will shape the future seascape.

Supplementary Materials: The following are available online at https://www.mdpi.com/article/ 10.3390/w13070997/s1, Table S1: Zooplankton density, Table S2: Pairwise tests contrasting the percentage of polyp expansion, Table S3: Pairwise tests contrasting the gut contents.

Author Contributions: Conceptualization, S.R. and L.R.; methodology, S.R.; formal analysis, S.R and L.R.; writing—original draft preparation, S.R. and L.R.; writing—review and editing, S.R. and L.R. Both authors have read and agreed to the published version of the manuscript.

Funding: This research was funded by an F.P.I. fellowship from Spain's Ministry of Education and Science to SR under projects DGICYT 1995e1998, PB94-0014-C02, as well as by the Marie Curie International Outgoing Fellowship (ANIMAL FOREST HEALTH, Grant Agreement Number 327845) and P-SPHERE (COFUND Marie Curie, Grant Agreement Number 665919).

Institutional Review Board Statement: Not applicable.

Informed Consent Statement: Not applicable.

Data Availability Statement: The data presented in this study are available on request from the corresponding author.

Acknowledgments: We are grateful for the critical comments made by Lorenzo Bramanti, who shed light in some key points of the manuscript. We also want to thank Helena Pardell, Elisabetta Broglio, and Elisabet Reyes for their help in quantifying seston concentration, including zooplankton. We are also grateful to thank Rafel Coma, Marta Ribes, David Diaz, Bernat Hereu, Marc Marí, and Emilià Pola for field assistance.

Conflicts of Interest: The authors declare no conflict of interest.

\section{References}

1. Arntz, W.E.; Gili, J.M.; Reise, K. Unjustifiably Ignored: Reflections on the Role of Benthos in Marine Ecosystems. In Biogeochemical Cycling and Sediment Ecology; Springer: Dordrecht, The Netherlands, 1999; pp. 105-124.

2. Gili, J.-M.; Coma, R. Benthic suspension feeders: Their paramount role in littoral marine food webs. Trends Ecol. Evol. 1998, 13, 316-321. [CrossRef]

3. Rossi, S. The destruction of the 'animal forests' in the oceans: Towards an over-simplification of the benthic ecosystems. Ocean Coast. Manag. 2013, 84,77-85. [CrossRef]

4. Rossi, S.; Bramanti, L.; Gori, A.; Orejas, C. Animal Forests of the World: An Overview. In Marine Animal Forests; Rossi, S., Bramanti, L., Gori, A., Orejas, C., Eds.; Springer International Publishing: Berlin/Heidelberg, Germany, 2017; pp. 1-28.

5. Guizien, K.; Ghisalberti, M. Living in the Canopy of the Animal Forest: Physical and Biogeochemical Aspects. In Marine Animal Forests; Rossi, S., Bra-manti, L., Gori, A., Orejas, C., Eds.; Springer International Publishing: Berlin/Heidelberg, Germany, 2017; pp. 507-528.

6. Barnes, D.; Clarke, A. Seasonality of feeding activity in Antarctic suspension feeders. Polar Biol. 1995, 15, 335-340. [CrossRef]

7. Lesser, M.P. Benthic-pelagic coupling on coral reefs: Feeding and growth of Caribbean sponges. J. Exp. Mar. Biol. Ecol. 2006, 328, 277-288. [CrossRef]

8. Iglesias, J.; Navarro, E.; Jorna, P.A.; Armentina, I. Feeding, particle selection and absorption in cockles Cerastoderma edule (L.) exposed to variable conditions of food concentration and quality. J. Exp. Mar. Biol. Ecol. 1992, 162, 177-198. [CrossRef]

9. Navarro, J.; Thompson, R. Seasonal fluctuations in the size spectra, biochemical composition and nutritive value of the seston available to a suspension-feeding bivalve in a subarctic environment. Mar. Ecol. Prog. Ser. 1995, 125, 95-106. [CrossRef]

10. Rossi, S.; Gili, J.-M. Short-time-scale variability of near-bottom seston composition during spring in a warm temperate sea. Hydrobiologia 2006, 575, 373-388. [CrossRef]

11. Rossi, S.; Fiorillo, I. Biochemical features of a Protoceratium reticulatum red tide in Chipana Bay (Northern Chile) in summer conditions. Sci. Mar. 2010, 74, 633-642. [CrossRef]

12. Naylor, E. Rhythmic behaviour and reproduction in marine animals. In Adaptation to Environment; Elsevier BV: Amsterdam, The Netherlands, 1976; pp. 393-429.

13. Maire, O.; Duchêne, J.C.; Amouroux, J.M.; Grémare, A. Activity patterns in the terebellid polychaete Eupolymnia nebulosa assessed using a new image analysis system. Mar. Biol. 2007, 151, 737-749. [CrossRef] 
14. Duchêne, J.-C. Activity Rhythm Measurement in Suspension Feeders. In Marine Animal Forests; Rossi, S., Bramanti, L., Gori, A., Orejas, C., Eds.; Springer International Publishing: Berlin/Heidelberg, Germany, 2017; pp. 761-785.

15. Rossi, S.; Rizzo, L.; Duchêne, J.-C. Polyp expansion of passive suspension feeders: A red coral case study. PeerJ 2019,7 , e7076. [CrossRef] [PubMed]

16. Ambrose, W.G.; Renaud, P.E. Does a pulsed food supply to the benthos affect polychaete recruitment patterns in the Northeast Water Polynya? J. Mar. Syst. 1997, 10, 483-495. [CrossRef]

17. Shimanaga, M.; Shirayama, Y. Response of benthic organisms to seasonal change of organic matter deposition in the bathyal Sagami Bay, central Japan. Oceanol. Acta 2000, 23, 91-107. [CrossRef]

18. Smith, K.; Baldwin, R.; Karl, D.; Boetius, A. Benthic community responses to pulses in pelagic food supply: North Pacific Subtropical Gyre. Deep. Sea Res. Part I Oceanogr. Res. Pap. 2002, 49, 971-990. [CrossRef]

19. Aberle, N.; Witte, U. Deep-sea macrofauna exposed to a simulated sedimentation event in the abyssal NE Atlantic: In situ pulse-chase experiments using 13C-labelled phytodetritus. Mar. Ecol. Prog. Ser. 2003, 251, 37-47. [CrossRef]

20. Campanyà-Llovet, N.; Snelgrove, P.V.; Parrish, C.C. Rethinking the importance of food quality in marine benthic food webs. Prog. Oceanogr. 2017, 156, 240-251. [CrossRef]

21. Rossi, S.; Isla, E.; Bosch-Belmar, M.; Galli, G.; Gori, A.; Gristina, M.; Ingrosso, G.; Milisenda, G.; Piraino, S.; Rizzo, L.; et al. Changes of energy fluxes in marine animal forests of the Anthropocene: Factors shaping the future seascape. ICES J. Mar. Sci. 2019, 76, 2008-2019. [CrossRef]

22. Rossi, S.; Gili, J.M. Near bottom phytoplankton and seston: Importance in the pelagic-benthic coupling processes. In Marine Phytoplankton; Kersey, W.T., Munger, S.P., Eds.; Nova Science Publishers Inc.: New York, NY, USA, 2009; pp. 45-85. ISBN 978-1-60741-087-4.

23. Gili, J.-M.; Rossi, S.; Pagès, F.; Orejas, C.; Teixidó, N.; López-González, P.J.; Arntz, W.E. A new trophic link between the pelagic and benthic systems on the Antarctic shelf. Mar. Ecol. Prog. Ser. 2006, 322, 43-49. [CrossRef]

24. Tsounis, G.; Rossi, S.; Laudien, J.; Bramanti, L.; Fernández, N.; Gili, J.-M.; Arntz, W.E. Diet and seasonal prey capture rates in the Mediterranean red coral (Corallium rubrum L.). Mar. Biol. 2006, 149, 313-325. [CrossRef]

25. Rossi, S.; Schubert, N.; Brown, D.; Gonzalez-Posada, A.; Soares, M.O. Trophic ecology of Caribbean octocorals: Autotrophic and heterotrophic seasonal trends. Coral Reefs 2020, 39, 433-449. [CrossRef]

26. Hughes, R.N. Optimal foraging theory in the marine context. Ocenogr. Mar. Biol. Ann. Rev. 1980, $18,423-481$.

27. Nelson, H.; Bramanti, L. From trees to octocorals: The role of self-thinning and shading in underwater animal forests. In Perspectives on the Marine Animal Forests of the World; Rossi, S., Bramanti, L., Eds.; Springer-Nature: Cham, Switzerland, 2020.

28. Coma, R.; Ribes, M.; Gili, J.; Hughes, R. The ultimate opportunists: Consumers of seston. Mar. Ecol. Prog. Ser. 2001, 219, 305-308. [CrossRef]

29. Lasker, H.R.; Gottfried, M.D.; Coffroth, M.A. Effects of depth on the feeding capabilities of two octocorals. Mar. Biol. 1983, 73, 73-78. [CrossRef]

30. Coma, R.; Gili, J.-M.; Zabala, M.; Riera, T. Feeding and prey capture cycles in the aposymbiontic gorgonian Paramuricea clavata. Mar. Ecol. Prog. Ser. 1994, 115, 257-270. [CrossRef]

31. Orejas, C.; Gili, J.; López-González, P.J.; Arntz, W. Feeding strategies and diet composition of four Antarctic cnidarian species. Polar Biol. 2001, 24, 620-627. [CrossRef]

32. Sánchez, J.A. Diversity and Evolution of Octocoral Animal Forests at Both Sides of Tropical America. In Marine Animal Forests; Rossi, S., Bramanti, L., Gori, A., Orejas, C., Eds.; Springer International Publishing: Berlin/Heidelberg, Germany, 2017; pp. 111143.

33. Ponti, M.; Turicchia, E.; Costantini, F.; Gori, A.; Bramanti, L.; di Camillo, C.G.; Linares, C.; Rossi, S.; Abbiati, M.; Garrabou, J.; et al. Mediterranean gorgonian forests: Distribution patterns and ecological roles. In Proceedings of the 3ème Symposium Méditerranéen Sur la Conservation du Coralligène at Autres Bio-Concrétions, Antalya, Turquie, 15-16 January 2019; pp. 7-14.

34. Coma, R.; Llorente-Llurba, E.; Serrano, E.; Gili, J.-M.; Ribes, M. Natural heterotrophic feeding by a temperate octocoral with symbiotic zooxanthellae: A contribution to understanding the mechanisms of die-off events. Coral Reefs 2015, 34, 549-560. [CrossRef]

35. Ferrier-Pagès, C.; Reynaud, S.; Beraud, E.; Rottier, C.; Menu, D.; Duong, G.; Gevaert, F. Photophysiology and daily primary production of a temperate symbiotic gorgonian. Photosynth. Res. 2014, 123, 95-104. [CrossRef]

36. Gori, A.; Rossi, S.; Berganzo, E.; Pretus, J.L.; Dale, M.R.T.; Gili, J.-M. Spatial distribution patterns of the gorgonians Eunicella singularis, Paramuricea clavata, and Leptogorgia sarmentosa (Cape of Creus, Northwestern Mediterranean Sea). Mar. Biol. 2011, 158, 143-158. [CrossRef]

37. Gori, A.; Rossi, S.; Linares, C.; Berganzo, E.; Orejas, C.; Dale, M.R.; Gili, J.-M. Size and spatial structure in deep versus shallow populations of the Mediterranean gorgonian Eunicella singularis (Cap de Creus, northwestern Mediterranean Sea). Mar. Biol. 2011, 158, 1721-1732. [CrossRef]

38. Gori, A.; Viladrich, N.; Gili, J.-M.; Kotta, M.; Cucio, C.; Magni, L.; Bramanti, L.; Rossi, S. Reproductive cycle and trophic ecology in deep versus shallow populations of the Mediterranean gorgonian Eunicella singularis (Cap de Creus, northwestern Mediterranean Sea). Coral Reefs 2012, 31, 823-837. [CrossRef]

39. Ribes, M.; Coma, R.; Gili, J.-M. Heterotrophic feeding by gorgonian corals with symbiotic zooxanthella. Limnol. Oceanogr. 1998, 43, 1170-1179. [CrossRef] 
40. Ribes, M.; Coma, R.; Rossi, S. Natural feeding of the temperate asymbiotic octocoral-gorgonian Leptogorgia sarmentosa (Cnidaria: Octocorallia). Mar. Ecol. Prog. Ser. 2003, 254, 141-150. [CrossRef]

41. Rossi, S.; Ribes, M.; Coma, R.; Gili, J.M. Temporal variability in zooplankton prey capture rate of the passive suspension feeder Leptogorgia sarmentosa (Cnidaria: Octocorallia), a case study. Mar. Biol. 2004, 144, 89-99. [CrossRef]

42. Sebens, K.P. Coelenterata. In Protozoa Through Insecta; Elsevier: Amsterdam, The Netherlands, 1987; pp. 55-120.

43. Sebens, K.P.; Koehl, M.A.R. Predation on zooplankton by the benthic anthozoans Alcyonium siderium (Alcyonacea) and Metridium senile (Actiniaria) in the New England subtidal. Mar. Biol. 1984, 81, 255-271. [CrossRef]

44. Hall, D.J.; Cooper, W.E.; Werner, E.E. An experimental approach to the production dynamics and structure of freshwater animal communities1. Limnol. Oceanogr. 1970, 15, 839-928. [CrossRef]

45. Beers, J.R. STUDIES ON THE CHEMICAL COMPOSITION OF THE MAJOR ZOOPLANKTON GROUPS IN THE SARGASSO SEA OFF BERMUDA1. Limnol. Oceanogr. 1966, 11, 520-528. [CrossRef]

46. Biswas, A.K.; Biswas, M.R. Handbook of Environmental Data and Ecological Parameters; Elsevier BV: Amsterdam, The Netherlands, 1979.

47. Anderson, M.J. A new method for non-parametric multivariate analysis of variance. Austral Ecol. 2001, 26, 32-46. [CrossRef]

48. Anderson, M.; Ter Braak, C. Permutation tests for multi-factorial analysis of variance. J. Stat. Comput. Simul. 2003, 73, 85-113. [CrossRef]

49. Clarke, K.R.; Gorley, R.N. Primer V6: User Manual/Tutorial; Plymouth Marine Laboratory: Plymouth, UK, 2006.

50. Anderson, M.J. Animal-sediment relationships re-visited: Characterising species' distributions along an environmental gradient using canonical analysis and quantile regression splines. J. Exp. Mar. Biol. Ecol. 2008, 366, 16-27. [CrossRef]

51. Sebens, K.; Sarà, G.; Nishizaki, M. Energetics, Particle Capture, and Growth Dynamics of Benthic Suspension Feeders. In Marine Animal Forests; Rossi, S., Bramanti, L., Gori, A., Orejas, C., Eds.; Springer International Publishing: Berlin/Heidelberg, Germany, 2017; pp. 813-854.

52. Rossi, S.; Gili, J.-M. Composition and temporal variation of the near-bottom seston in a Mediterranean coastal area. Estuar. Coast. Shelf Sci. 2005, 65, 385-395. [CrossRef]

53. Ribes, M.; Coma, R.; Gili, J. Seasonal variation of particulate organic carbon, dissolved organic carbon and the contribution of microbial communities to the live particulate organic carbon in a shallow near-bottom ecosystem at the Northwestern Mediterranean Sea. J. Plankton Res. 1999, 21, 1077-1100. [CrossRef]

54. Calbet, A.; Garrido, S.; Saiz, E.; Alcaraz, M.; Duarte, C.M. Annual Zooplankton Succession in Coastal NW Mediterranean Waters: The Importance of the Smaller Size Fractions. J. Plankton Res. 2001, 23, 319-331. [CrossRef]

55. Barange, M.; Gili, J.M. Feeding cycles and prey capture in Eudendrium racemosum (Cavolini, 1785). J. Exp. Mar. Biol. Ecol. 1988, 115, 281-293. [CrossRef]

56. Previati, M.; Scinto, A.; Cerrano, C.; Osinga, R. Oxygen consumption in Mediterranean octocorals under different temperatures. J. Exp. Mar. Biol. Ecol. 2010, 390, 39-48. [CrossRef]

57. Lessin, G.; Bruggeman, J.; McNeill, C.L.; Widdicombe, S. Time Scales of Benthic Macrofaunal Response to Pelagic Production Differ Between Major Feeding Groups. Front. Mar. Sci. 2019, 6, 6. [CrossRef]

58. Rossi, S.; Coppari, M.; Viladrich, N. Benthic-Pelagic Coupling: New Perspectives in the Animal Forests. In Marine Animal Forests; Rossi, S., Bramanti, L., Gori, A., Orejas, C., Eds.; Springer International Publishing: Berlin/Heidelberg, Germany, 2017; pp. 855-885.

59. Linares, C.; Coma, R.; Garrabou, J.; Díaz, D.; Zabala, M. Size distribution, density and disturbance in two Mediterranean gorgonians: Paramuricea clavata and Eunicella singularis. J. Appl. Ecol. 2008, 45, 688-699. [CrossRef]

60. Coma, R.; Linares, C.; Ribes, M.; Díaz, D.; Garrabou, J.; Ballesteros, E. Consequences of a mass mortality in populations of Eunicella singularis (Cnidaria: Octocorallia) in Menorca (NW Mediterranean). Mar. Ecol. Prog. Ser. 2006, 327, 51-60. [CrossRef]

61. Rossi, S.; Schubert, N.; Brown, D.; Soares, M.D.O.; Grosso, V.; Rangel-Huerta, E.; Maldonado, E. Linking host morphology and symbiont performance in octocorals. Sci. Rep. 2018, 8, 12823. [CrossRef]

62. Rossi, S.; Gili, J.-M.; Garrofé, X. Net negative growth detected in a population of Leptogorgia sarmentosa: Quantifying the biomass loss in a benthic soft bottom-gravel gorgonian. Mar. Biol. 2011, 158, 1631-1643. [CrossRef]

63. Lewis, J.B.; Price, W.S. Feeding mechanisms and feeding strategies of Atlantic reef corals. J. Zool. 1975, 176, 527-544. [CrossRef]

64. Coppari, M.; Zanella, C.; Rossi, S. The importance of coastal gorgonians in the blue carbon budget. Sci. Rep. 2019, 9, 1-12. [CrossRef]

65. Rossi, S.; Rizzo, L. Marine animal forests as Carbon immobilizers or why we should preserve these three-dimensional alive structures. In Perspectives on the Marine Animal Forests of the World; Rossi, S., Bramanti, L., Eds.; Springer-Nature: Cham, Switzerland, 2020. 